\title{
INTEGRASI SOFTWARE DINAMIS AUTOGRAPH DALAM PEMBELAJARAN MATEMATIKA MENGGUNAKAN PENDEKATAN PENEMUAN TERBIMBING
}

\author{
Ida Karnasih ${ }^{\text {a }}$, Abu Rahman ${ }^{\text {b }}$ \\ Program Studi Pendidikan Matematika Pascasarjana, UNIMED Medan \\ Jl. Willem Iskandar, Medan, \\ aikarnasih2001@yahoo.com \\ baburahman@yahoo.com
}

\begin{abstract}
ABSTRAK
Artikel ini menyajikan hasil penelitian yang menyelidiki keefektifan software dinamis AUTOGRAPH dalam belajar Aljabar di SMA menggunakan pendekatan penemuan terbimbing. Penelitian eksperimen semu ini berfokus pada kemampuan pemahaman dan penalaran matematika siswa dalam mempelajari fungsi kuadrat. 70 orang siswa terlibat dalam penelitian ini yang terdiri dari dua kelas, yaitu 35 siswa di kelas eksperimen dan 35 siswa di kelas kontrol. Siswa dikelompok eksperimen belajar dengan bantuan software AUTOGRAPH, sedangkan di kelompok kontrol siswa belajar tanpa bantuan software AUTOGRAPH. Di kedua kelas, siswa belajar menggunakan pendekatan penemuan terbimbing. Analisis statistik inferensial digunakan untuk melihat apakah terdapat perbedaan yang signifikan antara kemampuan pemahaman dan penalaran matematika siswa dikelompok eksperimen dan kelompok kontrol. Analisis deskriptif digunakan untuk menelaah sikap siswa terhadap matematika dan terhadap pembelajaran dengan menggunakan penemuan terbimbing berbantuan software AUTOGRAPH. Hasil penelitian menunjukkan keunggulan kelompok eksperimen untuk kemampuan pemahaman dan penalaran, sikap siswa dan aktivitas pembelajaran menggunakan AUTOGRAPH. Skor rata-rata keseluruhan kemampuan pemahaman kelompok eksperimen adalah $77,70(\mathrm{~s}=8,77)$ lebih tinggi dari rata-rata kelompok kontrol yaitu 70,20 (s =12,16). Rata-rata kemampuan penalaran matematika kelompok eksperimen adalah 78,90 $(\mathrm{s}=9,07)$ lebih tinggi dari rata-rata kelompok kontrol yaitu 70,10 $(\mathrm{s}=11,97$.$) Hasil$ analisis aktivitas pembelajaran siswa di kelas eksperimen selama pembelajaran lebih baik dari pada aktivitas pembelajaran di kelas kontrol, dan sikap siswa selama mengikuti pembelajaran matematika dengan pendekatan penemuan terbimbing menggunakan software AUTOGRAPH jauh lebih baik dan positif, serta siswa memiliki motivasi belajar yang tinggi. Dari hasil penelitian ini dapat disimpulkan bahwa software AUTOGRAPH efektif digunakan dalam mengajar fungsi kuadrat di SMA. Berdasarkan hasil penelitian ini disarankan agar guru menggunakan software dinamis dalam mengajar matematika untuk meningkatkan kualitas pembelajaran matematika untuk berbagai topik di SMA.
\end{abstract}

Kata kunci : Autograph, Penemuan Terbimbing, Kemampuan Pemahaman, Kemampuan Penalaran, Sikap terhadap Matematika

\begin{abstract}
This study as carried out to investigate the effectiveness of dynamic software AUTOGRAPH in learning Algebra in high school using guided discovery approach. This quasiexperimental research focused on students' mathematical understanding and reasoning abilities in learning quadratic functions. 70 students involved in this study consisted of two classes, 35 students involved in the experimental class and 35 students in the control class. Students in the experimental group learning with the help of software AUTOGRAPH, whereas in the control group students learning without the help of software AUTOGRAPH. In both classes, students learned using Guided Discovery Approach. Inferential statistical analysis was used to investigate whether there were significant differences between students' comprehension and mathematical reasoning
\end{abstract}


abilities in the experimental and control groups. Descriptive analysis was used to examine the students' attitudes towards mathematics and towards learning using guided discovery aided by software AUTOGRAPH. The results showed superiority for the experimental group in the students' understanding and reasoning ability, attitude and in students' learning activities using AUTOGRAPH. The average score of the overall ability of understanding in the experimental group was $77.70(\mathrm{~s}=8.77)$ and the average score of the control group was $70.20(\mathrm{~s}=12.16)$. The average of mathematical reasoning ability in the experimental group was $78.90(\mathrm{~s}=9.07)$ and the average of the control group was $70.10(\mathrm{~s}=11.97$. $)$ The results of the analysis of the learning activities of students in the experimental class was better than those of the control class, and student's attitudes during the learning of mathematics with guided discovery approach using software AUTOGRAPH was much better and positive, and students had higher motivation to learn. From these results, it can be concluded that the Autograph software was effectively used in teaching quadratic function in SMA. Based on the results of this study, it is suggested that teachers have to use technology teaching mathematics to improve the quality of teaching and learning mathematics in high school for a variety of topics.

Keywords : Dynamic Software Autograph, Guided Discovery, Mathematical Understanding, mathematical Reasoning, Attitude toward mathematics.

\section{Pendahuluan}

Penggunaan teknologi dalam kehidupan saat ini telah mempengaruhi lembaga-lembaga pendikan untuk mulai melakukan perubahan diberbagai aspek termasuk cara pengajaran dan disain kurikulumnya. Perkembangan teknologi secara kontinu telah menggerakkan dunia Internasional maupun Nasional untuk mengikuti perkembangan ini. Direktur UNESCO untuk regional Asia and Pacific, Sheldon Shaeffer pada pertemuan di Bangkok 2006, telah mencanangkan The Next Gen Project untuk guru-guru dan menyatakan sebagai berikut:

"By 2008, all regional Member States will be in a position to offer teachers an education on how and when to best use technologies for teaching and learning, through training which is integrated in all national pre-service teacher training institutions in the AsiaPacific region. Learners will directly benefit from this new generation of well educated teachers, who will be empowered to use technologies and to facilitate the learners' active participation in learning, and in the knowledge societies and economies."

Dari ungkapan di atas diharapkan setiap Negara di Asia Pasifik harus mempersiapkan guru untuk dididik dan dilatih bagaimana dan kapan menggunakan teknologi dengan baik dalam pembelajaran melalui program pendidikan pre-service maupun in-service. Tujuan utamanya adalah agar guru mampu memfasilitasi anak supaya aktif berpartisipasi dalam pembelajaran menggunakan teknologi. Dengan adanya perkembangan teknologi ini, kurikulum baru 2013 Indonesia telah mengalami beberapa perubahan, diantaranya perubahan dalam pedagogi yang mengarah ke pendekatan saintifik dan penggunaan TIK dan media yang telah disarankan dalam pembelajaran untuk semua mata pelajaran di Sekolah 
Menengah, termasuk matematika (Depdikbud, 2013).

Di beberapa sekolah, sebelum adanya kurikulum baru, telah banyak guruguru matematika yang menerapkan teknologi dalam mengajar maupun melakukan penelitian. Penggunaan software aplikasi, seperti AUTOGRAPH, dalam pembelajaran matematika telah mulai diujiobakan. Namun, kemampuan guru merancang dan melaksanakan pembelajaran dengan mengintegrasikan teknologi dan hasil penerapan teknologi ini masih perlu dikaji baik dalam perencanaan, pelaksanaan pembelajarannya serta dampaknya terhadap hasil belajarnya.

Permasalahan ketrampilan berfikir, pemahaman dan penalaran matematis masih menjadi tantangan pendidikan matematika yang harus dihadapi dan ditangani masa kini. Banyak hal yang mempengaruhi masalah ini. Salah satu penyebabnya adalah proses pembelajaran yang masih berpusat pada guru dan pembelajaran yang padanya masih menggunakan pensil dan kertas. Siswa jarang dilibatkan secara aktif dalam belajar ataupun mengkonstruksi pengetahuannya melalui penggunaan media maupun teknologi yang tersedia.

Penemuan terbimbing (guided inquiry) merupakan salah satu alternatif metode yang mengarah ke pembelajaran saintifik, dimana dengan penemuan terbimbing siswa menyelidiki, menginvestigasi, mencoba, dan akhirnya menemukan sendiri konsep matematika yang dimaksud. Dengan menggunakan pendekatan ini siswa terlibat aktif bekerja sama mencari, menggali, mengeksplorasi, mencoba-coba, menyelidiki dari berbagai keadaan, untuk menemukan dan mengkonstruksi ide baru, pengetahuan baru, berdasarkan berbagai sumber informasi dan pengetahuan awal atau konsep yang telah dikuasai sebelumnya.

Penggunaan media komputer dalam pembelajaran matematika di sekolah masih belum dioptimalkan. Fokus pembelajaran masih lebih kepada komputasi dan menggambar grafik dan bukan pada pengembangan ketrampilan berfikir (developing thinking skills).

Kurikulum 2013 menuntut penggunaan TIK dan media di Sekolah Menengah. Namun, kenyataan program pelaksanaannya di sekolah masih terkendala dan guru belum siap menghadapi tuntutan baru ini. Guru perlu dipersiapkan untuk memiliki kompetensi dalam menggunakan teknologi dan mengajar matematika menggunakan teknologi. Dengan bantuan software dinamis dikombinasikan dengan penemuan terbimbing, siswa diharapkan akan mampu melaksanakan proses belajar dengan lebih luwes dan mereka dengan bebas dapat mencoba-coba berulang kali sampai akhirnya siswa memahami konsep yang dipelajari dan dapat menemukan simpulan tentang apa yang dipelajarinya.

$$
\text { Briggs dan Bennett }
$$
menyatakan bahwa setiap bagian dari teknologi yang digunakan akan mengurangi waktu pengajaran. Dengan perencanaan pelajaran dan pelaksanaannya yang tepat, penggunaan software seperti Autograph tidak akan membuang-buang 
waktu danp roses pembelajaran lebih efektif dan efisien. Pene-litian menggunakan teknologi dalam pembelajaran matematika ini perlu dikaji dampaknya terhadap aspek kognitif, afektif maupun ketrampilan belajar siswa.

Berdasarkan uraian latar belakang di atas, rumusan masalah dalam penelitian ini adalah (1) Apakah kemampuan pemahaman dan penalaran matematika siswa dengan penemuan terbimbing berbantuan Software Autograph lebih tinggi daripada kemampuan pemahaman dan penalaran siswa yang belajar dengan penemuan terbimbing tanpa Autograph? (2) Bagai-manakah sikap siswa terhadap terhadap pembelajaran dengan penemuan terbim-bing berbantuan Software Autograph; (3) Bagaimanakah tingkat aktivitas belajar siswa dengan penemuan terbimbing bebantuan Software Autograph.

\section{Kajian Literatur}

\section{Pemahaman Matematika}

Kata pemahaman mengandung arti kesanggupan intelegensi untuk menangkap makna suatu situasi atau perbuatan (Depdikbud, 1989). Dalam belajar matematika, adanya kesanggupan intelegensi siswa untuk menangkap makna konsep-konsep tertentu dalam materi pembelajaran menunjukkan akan adanya pemahaman yang kelak dicapai siswa tersebut. Bagi siswa yang belajar matematika dengan pemahaman diharapkan tumbuhnya kemampuan siswa untuk mengkomunikasikan dan mengaplikasikan konsep yang telah dipahaminya dalam dunia nyata.
Bloom (dalam Ruseffendi,1988: 221) membagi pemahaman atas tiga macam yaitu: pemahaman translasi, pemahaman interpretasi, dan pemahaman extrapolasi. Pemahaman translasi (kemampuan mengubah) adalah kemampuan mengubah simbol tertentu menjadi simbol lain tanpa perubahan makna. Pemahaman interpretasi (kemampuan menafsirkan) berkaitan dengan kemampuan - kemampuan siswa dalam menentukan konsep-konsep yang tepat untuk digunakan dalam menyelesaikan soal/ masalah yang dihadapinya. Sedangkan pemahaman ekstrapolasi (kemampuan meramalkan) adalah kemampuan meramalkan kecenderungan yang ada menurut data tertentu dengan mengutarakan konsekuensi dan implikasi yang sejalan dengan kondisi yang digambarkan. Menurut Hasanah (2004:23) terbentuknya pemahaman dalam kegiatan belajar terjadi melalui proses yang dapat digambarkan seperti berikut :

a. Menangkap ide yang dipelajari melalui pengamatan yang dilakukan.

b. Menggabungkan informasi yang baru dengan skema pengetahuan yang telah ada.

c. Mengorganisasikan kembali pengetahuan yang telah terbentuk.

Selanjutnya, Hiebert dan Carpenter (Grouws, 1992: 72-75) mengemukakan sejumlah konsekuensi positif terhadap pengetahuan yang diperoleh dalam belajar matematika dengan pemahaman, yaitu sebagai berikut:

a. Bersifat Generatif. Artinya, pengetahuan yang terbentuk dari hasil 
belajar dengan pengertian sewaktuwaktu dapat dimunculkan kembali (distimulasi).

b. Bermakna.

c. Memperkuat ingatan dan mengurangi jumlah informasi yang harus dihafal.

d. Memudahkan transfer belajar. Mempengaruhi kepercayaan.

\section{Penalaran Matematika}

Fondasi dari belajar matematika adalah penalaran (reasoning) yang didefinisikan sebagai proses pencapaian kesimpulan logis berdasarkan fakta-fakta dan sumber yang relevan (Shurter \& Pierce dalam Jarnawi 2003:19), pentransformasian yang diberikan dalam urutan tertentu untuk menjangkau kesimpulan (Galloti dalam Jarnawi, 2003:19). Matematika dan penalaran matematika merupakan dua hal yang tidak dapat dipisahkan, yaitu materi matematika dipahami melalui penalaran dan penalaran dipahami dan dilatih melalui belajar matematika (Depdiknas, 2006).

Secara garis besar terdapat dua jenis penalaran, yaitu penalaran induktif dan penalaran deduktif. Penalaran induktif sebagai proses penalaran yang menurunkan prinsip atau aturan umum dari pengamatan hal-hal atau contoh-contoh khusus (Shurter dan Pierce (dalam Jarnawi, 2003:19). Penalaran deduktif adalah proses penalaran yang konklusinya diturunkan secara mutlak menurut premispremisnya, dan argumen induktif adalah proses penalaran yang kesimpulannya diturunkan menurut premis-premisnya.
NCTM (1989) menjelaskan bahwa penalaran matematika sebagai konseptualisasi dinamik dari daya matematika (mathematical power) siswa, yang memandang penalaran matematika sebagai aktivitas dinamik yang melibatkan keragaman mode berpikir. Daya matematika merupakan integrasi dari halhal berikut ini: (a) suatu kecenderungan positif kepada matematika; (b) pengetahuan dan pemahaman terhadap sifat-sifat matematika, meliputi konsep-konsep, prosedur-prosedur dan keterampilanketerampilan; (c) kecakapan melakukan analisis dan beralasan secara matematis; (d) kecakapan menggunakan bahasa matematika untuk mengkomunikasikan ide-ide; dan (e) kecakapan menerapkan pengetahuan matematika untuk memecahkan masalah-masalah dalam berbagai konteks dan disiplin ilmu.

Untuk memperoleh pemahaman dan penalaran, NCTM merekomendasikan pembelajaran matematika yang menitikberatkan pada:

1. Penyelesaian masalah, tidak hanya mengingat prosedur (seeking solution, not just memorizing procedures).

2. Pengeksplorasian pola, tidak hanya mengingat rumus (exploring pattern, not just memorizing formula).

3. Memformulasi dugaan, tidak hanya mengerjakan latihan rutin (formulating conjecture, not just routin exercise).

Rekomendasi di atas mengacu kepada pandangan matematika yang dikemukakan oleh Schoenfeld (Jarnawi, 2003:24) yakni kegiatan belajar matematika dipandang sebagai suatu 
proses yang aktif dan generatif yang dikerjakan oleh pelaku dan pengguna matematika. Proses matematika yang aktif tersebut memuat penggunaan alat matematika secara sistematik untuk menemukan pola, kerangka masalah dan menetapkan proses penalaran.

Soekadijo (1999:134) mengatakan penalaran induktif terdiri dari tiga jenis, yaitu generalisasi, analogi, dan sebabakibat. Generalisasi adalah membuat perkiraan atau terkaan berdasarkan pada pengetahuan atau pengalaman yang dikembangkan melalui contoh-contoh khusus (Ruseffendi, 1988 : 267), dan analogi adalah membandingkan dua hal (situasi atau kondisi) yang berlainan berdasarkan keserupaannya, kemudian menarik kesimpulan atas dasar keserupaan tersebut. Dalam penelitian ini penalaran induktif yang dikaji adalah generalisasi dan analogi.

Penalaran deduktif adalah mentransformasikan informasi yang diberikan untuk memperoleh suatu konklusi. Penalaran deduktif adalah penalaran yang sesuai dengan aturan-aturan logika atau konsisten dengan aturan-aturan logika (Anggriamurti, 2009:2). Penalaran deduktif terbagi atas: (1) Penalaran kondisional berhubungan dengan pernyataan atau proposisi dan (2) penalaran silogistik atau silogisme memuat dua premis atau pernyataan yang harus kita asumsikan benar, ditambah suatu konklusi. Jenis-jenis penalaran deduktif yaitu modus ponens, modus tollens, dan silogisme. Modus ponens merupakan hubungan antara premis-premis. Penalaran modus tollens terdiri dari dua jenis yaitu menyangkal anteseden dan menyangkal konsekuen. Penalaran silogisme adalah bentuk pemikiran yang kesimpulannya muncul secara signifikan setelah ada pernyataan-pernyataan yang diturunkan secara mutlak. Silogisme terdiri dari dua premis atau dua pernyataan yang harus diasumsikan benar dan ditambah dengan suatu kesimpulan.

\section{Pendekatan Pembelajaran Penemuan Terbimbing}

Penemuan terbimbing adalah sebuah pendekatan pembelajaran di mana siswa menemukan dan menggunakan sumber informasi yang beragam dan ideide untuk meningkatkan pemahaman tentang suatu masalah, topik, atau isu (Kuhlthau, 2007). Pembelajaran penemuan terbimbing meliputi kegiatan investigasi, eksplorasi, pencarian, penyelidikan, dan penelitian.

Pada pembelajaran dengan penemuan, siswa didorong untuk belajar sebagian besar melalui keterlibatan aktif mereka sendiri dengan konsep-konsep dan prinsip-prinsip. Selain itu, dalam pembelajaran penemuan tebimbing, siswa belajar pemecahan masalah dan melatih keterampilan berpikir secara mandiri dan mereka harus menganalisis dan memanipulasi informasi (Kuhlthau, 2007). Namun dalam proses penemuan ini siswa mendapat bantuan atau bimbingan dari guru agar mereka lebih terarah sehingga baik proses pelaksanaan pembelajaran maupun tujuan yang dicapai terlaksana dengan baik. Bimbingan guru yang 
dimaksud adalah memberikan bantuan agar siswa dapat memahami tujuan kegiatan yang dilakukan dan berupa arahan tentang prosedur kerja yang perlu dilakukan dalam kegiatan pembelajaran (Kuhlthau, 2007).

Beberapa keuntungan pembelajaran penemuan terbimbing yaitu siswa belajar bagaimana belajar (learn how to learn), belajar menghargai diri sendiri, memotivasi diri dan lebih mudah untuk mentransfer, memperkecil atau menghindari menghafal dan siswa bertanggung jawab atas pembelajarannya sendiri (Kuhlthau, 2007). Pembelajaran penemuan terbimbing yang melibatkan teknologi membuat siswa melek sains dan teknologi, dan dapat memecahkan masalah, karena mereka benar-benar diberi kesempatan berperan serta di dalam kegiatan matematika sesuai dengan perkembangan intelektual mereka dengan bimbingan guru.

Pembelajaran penemuan terbimbing dikembangkan berdasarkan pandangan kognitif tentang pembelajaran dan prinsip-prinsip konstruktivis (Kuhlthau, 2007). Menurut prinsip ini siswa dilatih dan didorong untuk dapat belajar secara mandiri. Dengan kata lain, belajar secara konstruktivis lebih menekankan belajar berpusat pada siswa sedangkan peranan guru adalah membantu siswa menemukan fakta, konsep atau prinsip untuk diri mereka sendiri bukan memberikan ceramah atau mengendalikan seluruh kegiatan kelas.

Dalam penemuan terbimbing, pembelajaran menggunakan strategi intervensi yang memungkinkan siswa mengkonstruksi pemahaman sendiri. Guru sebagai fasilitator membantu siswa mencari fakta, menjelaskan dan mensintesa terhadap fakta-fakta. Strategi yang dimaksud menurut Kuhlthau (2007) terlihat pada Tabel 1 :

Tabel 1. Strategi Intervensi Penemuan Terbimbing

\section{Intervention Strategies for Guided Inquiry}

\section{The Six Cs}

1. collaborate Bekerja sama dengan yang (berkolaborasi) lain

2. converse Membicarakan tentang membicarakan kejelasan ide dan pertanyaan lebih jauh

3. continue
$\begin{aligned} & \text { Mengembangkan } \\ & \text { berkesinam- }\end{aligned}$
bungan)

4. choose Memilih apa yang penting (memilih) dan cocok

5. chart (grafik) Menggambarkan ide-ide menggunakan gambar, time line, dan grafik

6. compose Menuliskan semua langkah(menyusun) langkah, tidak hanya hasilnya, buat jurnalnya.

Manfaat pembelajaran penemuan terbimbing bagi siswa: (a) mengembangkan kecakapan sosial, bahasa, dan kemampuan membaca; (b) mengkonstruksi pemahaman sendiri; (c) meningkatkan kemandirian dalam meneliti dan belajar; (d) mempunyai motivasi yang tinggi pada waktu bekerja; (e) belajar strategi dan keterampilan dapat dioperkan ke proyek penemuan yang lain. Manfaat pembelajaran penemuan terbimbing bagi guru yakni: (a) berbagi tanggung jawab dalam tim pembelajaran; (b) berbagi keahlian dalam anggota tim; (c) keterampilan mengajar isi dan informasi secara bersamaan; (d) gagasan perencanaan yang 
lebih kreatif; (e) meningkatkan pengalaman terhadap isi kurikulum (Kuhlthau, 2007).

$$
\text { Kuhlthau (2007) memberikan }
$$

petunjuk dalam merencanakan dan menyiapkan pembelajaran penemuan terbimbing sebagai berikut: (1) Menentukan tujuan yang akan dipelajari oleh siswa. (2) Memilih metode yang sesuai dengan kegiatan penemuan. (3) Menentukan lembar pengamatan untuk siswa. (4) Menyiapkan alat dan bahan secara lengkap. (5) Menentukan dengan cermat apakah siswa akan bekerja secara individu atau secara kelompok yang terdiri dari 2,3 atau 4 siswa. (6) Mencoba terlebih dahulu kegiatan yang akan dikerjakan oleh siswa untuk mengetahui kesulitan yang mungkin timbul atau kemungkinan untuk modifikasi.

Agar pelaksanaan model penemuan terbimbing ini berjalan dengan efektif, beberapa langkah yang perlu ditempuh oleh guru matematika adalah sebagai berikut:

a. Merumuskan masalah yang akan diberikan kepada siswa dengan data secukupnya, perumusannya harus jelas, hindari pernyataan yang menimbulkan salah tafsir sehingga arah yang ditempuh siswa tidak salah.

b. Dari data yang diberikan guru, siswa menyusun, memproses, mengorganisir, dan menganalisis data tersebut. Dalam hal ini, bimbingan guru dapat diberikan sejauh yang diperlukan saja. Bimbingan ini sebaiknya mengarahkan siswa untuk melangkah ke arah yang hendak dituju, melalui pertanyaan- pertanyaan, atau LAS (lembaran aktivitas siswa).

c. Siswa menyusun konjektur (prakiraan) dari hasil analisis yang dilakukannya.

d. Bila dipandang perlu, konjektur yang telah dibuat siswa tersebut diatas diperiksa oleh guru. Hal ini penting dilakukan untuk meyakinkan kebenaran prakiraan siswa, sehingga akan menuju arah yang hendak dicapai.

e. Apabila telah diperoleh kepastian tentang kebenaran konjektur tersebut, maka verbalisasi konjektur sebaiknya diserahkan juga kepada siswa untuk menyusunya. Di samping itu perlu diingat pula bahwa induksi tidak menjamin 100\% kebenaran konjektur.

f. Sesudah siswa menemukan apa yang dicari, hendaknya guru menyediakan soal latihan atau soal tambahan untuk memeriksa apakah hasil penemuan itu benar (Markaban, 2006:16)

Memperhatikan Model Penemuan Terbimbing tersebut diatas dapat disampaikan kelebihan dan kekurangan yang dimilikinya. Kelebihan dari Model Penemuan Terbimbing adalah sebagai berikut (Marzano, 1992: 12):

a. Siswa dapat berpartisipasi aktif dalam pembelajaran yang disajikan.

b. Menumbuhkan sekaligus menanamkan sikap inquiry (mencari-temukan)

c. Mendukung kemampuan problem solving siswa.

d. Memberikan wahana interaksi antar siswa, maupun siswa dengan guru, dengan demikian siswa juga terlatih 
untuk menggunakan bahasa Indonesia yang baik dan benar.

e. Materi yang dipelajari dapat mencapai tingkat kemampuan yang tinggi dan lebih lama membekas karena siswa dilibatkan dalam proses menemukanya

\section{Integrasi Teknologi Dalam Pembelajaran Matematika}

Penggunaan teknologi termasuk salah satu dari enam prinsip matematika sekolah. NCTM (1991) menyatakan, "Technology is essential in teaching and learning mathematics; it influences the mathematics that is taught and enhances students' learning." Untuk penerapannya di kelas, penggunaan ICT dapat diintegrasikan dengan beberapa pendekatan belajar antara lain : belajar melalui ekspositori, inkuiri, belajar secara kooperatif, maupun individual. Dalam penelitian ini, pendekatan penemuan terbimbing dipadu dengan TIK sebagai alternatif untuk dapat meningkatkan pemahaman dan penalaran matematika siswa. Dengan Autograph, siswa dapat melakukan eksplorasi, investigasi, dan pencarian informasi. Siswa dapat menguji lebih banyak contoh dalam waktu singkat daripada hanya menggunakan tangan, sehingga dari ekperimennya siswa dapat menemukan, mengkonstruksi dan menyimpulkan prinsip-prinsip matematika, dan akhirnya paham bagaimana menggambar dan membaca grafik fungsi kuadrat dengan benar.

Dalam menerapkan teknologi dalam pembelajaran, guru harus mengembangkan konsepsi menyeluruh dari materi pelajaran yang berkaitan dengan teknologi dan mengajar dengan menggunakan teknologi. Shulman (1986) menyebutkannya sebagai 'Technological Pedagogial Content Knowledge' (TPCK) yaitu:

1. Memahami Materi yang akan diajarkan (Content knowledge)

2. Memahami dan dapat menerapkan pendekatan yang digunakan (Pedagogial knowledge).

3. Memahami dan dapat menggunakan teknologi yang telah dipersiapkan (Technological knowledge).

Dalam penelitian ini, materi yang diajarkan adalah fungsi kuadrat dan grafiknya dengan pendekatan penemuan terbimbing menggunakan bantuan teknologi interaktif AUTOGRAPH.

\section{Penggunaan Autograph Dalam Pembelajaran Matematika}

Penggunaan software dinamis Autograph membuat proses belajar dan mengajar menjadi lebih interaktif dan partisipatif (Butler, 2008). AUTOGRAPH merupakan program komputer yang sangat dinamis. Dalam operasi windows, penggunaannya menawarkan 3 pilihan yaitu: (a) 1D untuk Statistik; (b) 2D untuk Grafik, Koordinat, Transformasi dan Geometri; (c) 3D untuk Grafik, Koordinat dan Transformasi. AUTOGRAPH dalam penggunaannya memiliki dua level sistem operasi yaitu 'Standard' dan 'Advanced'. Untuk level 'Standard' dalam penggunaannya memberikan tampilan yang sangat sederhana, sedangkan pada level 'Advanced' memberikan pilihan yang 
lebih lengkap bagi pengguna sehingga dalam menyelesaikan masalah pengguna diberikan kebebasan dalam memilih (option) untuk digunakan dalam pemecahan masalah. Autograph sebagai salah satu media pembelajaran menitikberatkan peran aktif siswa dalam belajar eksplorasi dan investigasi. Desain Autograph melibatkan tiga prinsip utama dalam belajar, yaitu fleksibilitas, berulangulang, dan menarik simpulan. Prinsip ini sangat selaras dengan ciri-ciri penemuan terbimbing yang mengarahkan siswa pada pengalaman investigasi dalam belajar matematika.

Dengan bimbingan guru, penggunaan Autograph dalam belajar dapat membantu siswa menemukan konsepkonsep dan menyelesaikan masalah yang diberikan guru. Siswa dapat menguji lebih banyak contoh dalam waktu singkat, sehingga dari ekperimennya menggunakan teknologi siswa dapat menemukan, mengkonstruksi dan menyimpulkan prinsip-prinsip matematika serta mampu menggunakan konsep dalam aplikasinya.

\section{Pembelajaran Fungsi Kuadrat Dengan}

Penemuan Terbimbing Berbantuan Software Autograph

Langkah-langkah yang perlu ditempuh oleh guru matematika agar pelaksanaan pembelajaran fungsi kuadrat dengan pendekatan penemuan terbimbing menggunakan Autograph berjalan dengan efektif adalah sebagai berikut:

a. Sebelum pembelajaran dimulai, guru sudah memberikan pelatihan kepada siswa tentang penggunaan software
AUTOGRAPH yang berkenaan dengan pengetahuan prasyarat untuk mempelajari fungsi kuadrat.

b. Merumuskan indikator yang akan dicapai sebagai tujuan pembelajaran fungsi kuadrat, dimana perumusannya harus jelas dan menghindari pernyataan yang menimbulkan salah tafsir sehingga arah yang ditempuh siswa tidak salah.

c. Dalam mengelola kelas, guru mengelompokkan siswa dalam beberapa kelompok kecil, setiap kelompok menggunakan satu unit komputer.

d. Guru menyusun Lembaran Aktivitas Siswa (LAS) yang mengintegrasikan penggunaan AUTOGRAPH. LAS disusun sesuai dengan sintax penemuan terbimbing.

e. Siswa menyusun konjektur (prakiraan) secara individu maupun berkelompok dari hasil analisis yang dilakukannya.

f. Konjektur yang telah dibuat siswa tersebut diatas diperiksa oleh guru. Hal ini penting dilakukan untuk meyakinkan kebenaran prakiraan siswa, sehingga akan menuju arah yang hendak dicapai.

g. Apabila telah diperoleh kepastian tentang kebenaran konjektur tersebut, maka verbalisasi konjektur sebaiknya diserahkan juga kepada siswa untuk menyusunya.

h. Sesudah siswa menemukan apa yang dicari (pola-pola, formula atau aturanaturan), guru menyediakan soal latihan atau soal tambahan untuk memeriksa apakah hasil penemuan itu benar. 
Siswa diperintahkan untuk mengerjakan soal latihan secara manual kemudian untuk meyakinkan siswa memeriksa dengan AUTOGRAPH.

Berikut diberikan contoh kegiatan siswa selama belajar fungsi kuadrat dan grafik fungsi kuadrat dengan penemuan terbimbing dengan

software AUTOGRAPH :

1. Masing-masing kelompok siswa menggunakan komputer yang telah diinstalkan software AUTOGRAPH

2. Masing-masing siswa mendapatkan LAS yang juga berguna sebagai panduan selama melakukan percobaan

3. Siswa membuka Autograph dengan mendouble clik icon Autograph yang ada pada desktop atau dengan mengklik START $=>$ PROGRAMS $=$ AUTOGRAPH 3.20. Akan muncul worksheet dua dimensi seperti berikut

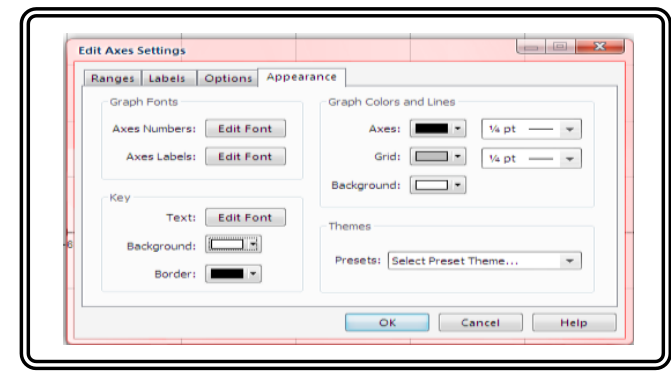

4. Untuk mengubah layarnya lebih menarik berbentuk kertas grafik, klik "edit axes"

5. Akan muncul layar seperti gambar berikut, klik "Appearance", kemudian klik "Select Preset Theme...", pilih "Graph Paper" Kemudian klik "OK" maka hasilnya seperti pada gambar berikut ini.

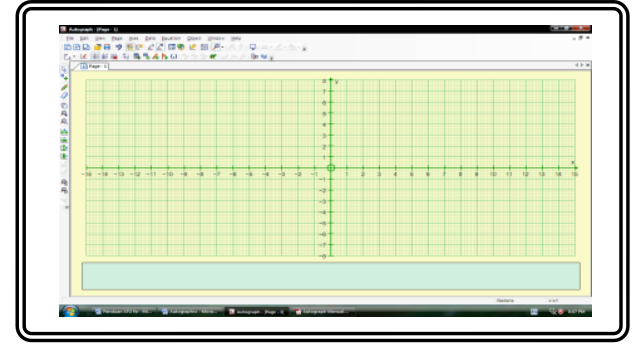

6. Memasukkan persamaan kuadrat, klik “enter equation" 费 atau klik kanan kemudian klik“"晶enter equation... Enter"

7. Pada kolom "Equation" ketik fungsi kuadrat yang diinginkan, misalnya ketik $\mathrm{y}=\mathrm{x}^{2}+4 \mathrm{x}-2$, kemudian klik "OK"

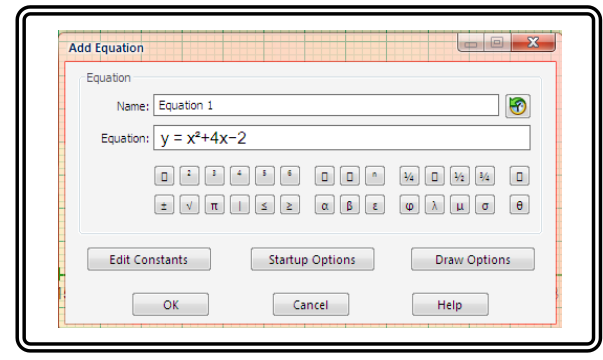

8. Hasilnya akan muncul seperti gambar berikut:

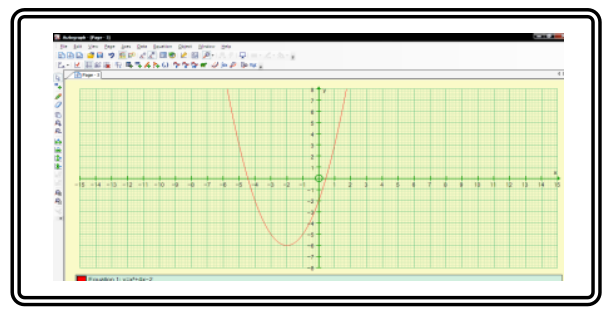

Jika ingin melihat isi "status bar" dapat dilakukan, caranya klik "View" => "Status Box". "status box" dapat dipindahkan atau diperbesar. Untuk menutupnya klik tanda silang pada sudut kanan atas.

9. Jika fungsi yang dimasukkan memiliki koefesien variabel seperti $\mathrm{y}=\mathrm{ax}^{2}+\mathrm{bx}+\mathrm{c}$, siswa dapat melihat pengaruh perubahan koefesien terhadap bentuk grafik dengan cara mengklik CONSTANT CONTROLLER . 


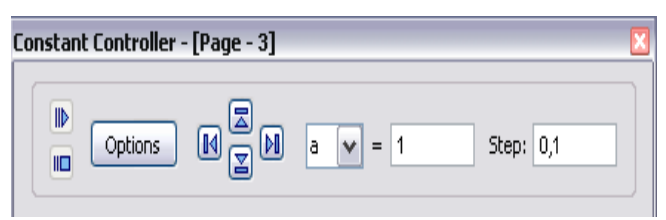

10. Akan muncul kotak seperti berikut

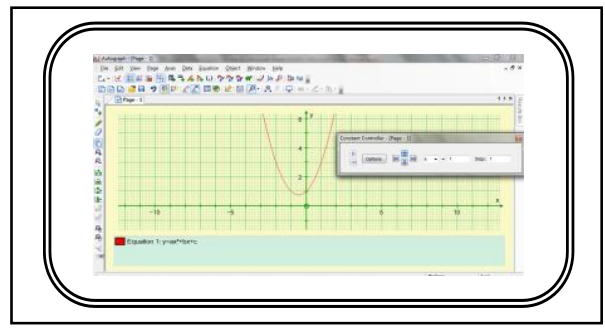

11. Dengan mengklik tombol 国 untuk menambah nilai a menjadi semakin besar dan mengklik tombol $\square$ untuk mengurangi nilai a menjadi semakin kecil, sama seperti nilai $a$, pengaruh $b$ dan $c$ juga dapat dilihat dengan cara mengklik tombol

国 atau tombol $\nabla$.

12. Selanjutnya siswa diberi gambar grafik $y=x^{2}$ dan 2 grafik yang berada di kanan dan kiri grafik. Kemudian siswa disuruh mengamati gambar menemukan persamaan grafik fungsi tersebut

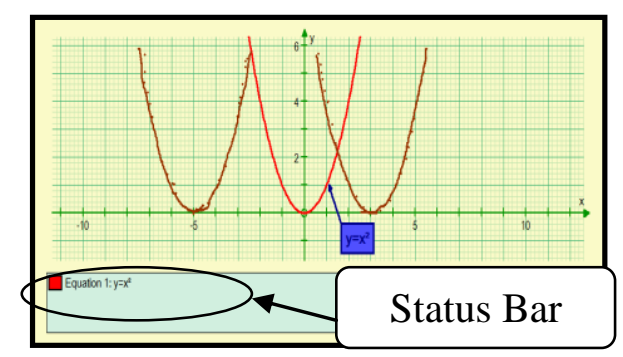

13. Untuk latihan animasi:
a. Ketik persamaan $\mathrm{y}=\mathrm{ax}^{2}$, a adalah variable
b. Klik constant controller
c. Klik 'option'
d. Pilih family plot
e. Klik OK
f. Maka akan diperoleh grafik seperti di samping

g. Untuk animasi, klik Option dan klik 'animation repeat' kemudian Klik OK,

h. Jalankan animasinya, dan diperoleh gambar seperti berikut:

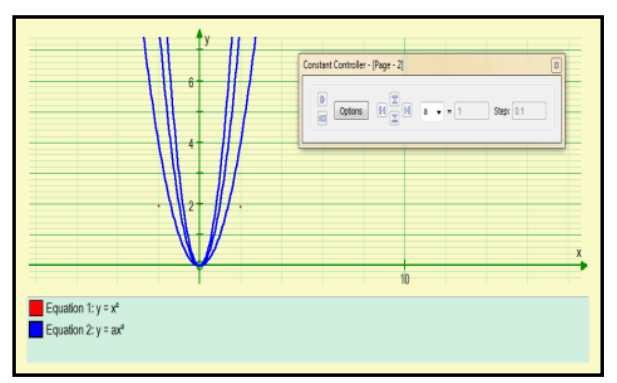

14. Setiap kali siswa mendapat hasil berupa gambar grafik dari Autograph, siswa kemudian menggambarkannya di LAS. Setelah beberapa kali percobaan, siswa berpikir untuk mengambil kesimpulan dan menuliskan kesimpulannya di LAS, misalnya siswa menyimpulkan cara menggambar grafik $y=(x-h)^{2}$, dengan $h$ sebagai variable dan kemudian menggambar grafik $\mathrm{y}=(\mathrm{x}-h)^{2}+\mathrm{k}$, dengan $\mathrm{h}$ dan $\mathrm{k}$ sebagai variable.

15. Akhirnya siswa menguji kesimpulannya. Hal ini dapat dilakukan dengan cara menggambar terlebih dahulu di LAS, misalnya grafik $\mathrm{y}=(\mathrm{x}-h)^{2}+k$ dengan konstanta $h$ atau $k$ yang dipilihnya. Setelah selesai menggambar di LAS siswa memeriksa dengan Autograph apakah gambar di LAS nya sama dengan yang ditunjukkan Autograph.

\section{Metodologi Penelitian}

Populasi dalam penelitian ini adalah seluruh siswa kelas X SMAN Seribu Bukit yang terdiri dari 2 kelas atau 70 orang siswa. Dari ke dua kelas tersebut 
dipilih secara acak satu kelompok sebagai kelas eksperimen dan kelompok yang lain sebagai kelas kontrol. Kelompok eksperimen terdiri dari 35 siswa diajar menggunakan pendekatan penemuan terbimbing berbantuan Software AUTOGRAPH, sedangkan kelompok kontrol terdiri dari 30 siswa menggunakan pendekatan penemuan terbimbing tanpa AUTOGRAPH.

Penelitian ini adalah penelitian eksperimen semu (quasi experiment) yang bertujuan untuk menyelidiki perbedaan kemampuan pemahaman dan kemampuan penalaran matematika antara kelompok siswa yang memperoleh pembelajaran dengan pendekatan penemuan terbimbing dengan menggunakan AUTOGRAPH dan tanpa software AUTOGRAPH.

Penelitian ini menggunakan desain penelitian sebagai berikut:

\begin{tabular}{|c|c|c|c|}
\hline $\mathrm{A}$ & $\mathrm{O}_{1}$ & $\mathrm{X}$ & $\mathrm{O}_{2}$ \\
\hline $\mathrm{A}$ & $\mathrm{O}_{1}$ & $\mathrm{Y}$ & $\mathrm{O}_{2}$ \\
\hline
\end{tabular}

Keterangan:

$\mathrm{A}=$ Pemilihan sample secara acak

$\mathrm{X}$ = Perlakuan berupa pembela-jaran menggunakan pendekat-an penemuan terbimbing de-ngan software AUTOGRAPH.

$\mathrm{Y}=$ Perlakuan berupa pembelajar-an menggunakan pendekatan penemuan terbimbing tanpa software AUTOGRAPH.

$\mathrm{O}_{1}=$ Tes pengetahuan materi prasyarat

$\mathrm{O}_{2}=$ Postes berupa tes kemampuan pemahaman matematika dan penalaran matematika.

Ada dua jenis instrument digunakan dalam penelitian ini yaitu tes dan non- tes. Instrumen jenis tes mencakup tes pengetahuan materi prasyarat (soal berbentuk tes uraian), tes kemampuan pemahaman matematika terdiri dari 8 soal bentuk pilihan ganda beralasan dan tes penalaran matematika berbentuk tes pilihan ganda beralasan. Sedangkan instrumen dalam bentuk non-tes mencakup skala sikap siswa dan lembar pengamatan aktivitas belajar siswa diberikan untuk masing-masing pembelajaran.

Teknik analisis data menggunakan uji t untuk menguji perbedaan kemampuan pemahaman dan penalaran matematika siswa kedua kelompok dengan sebelumnya menguji normalitas dan homogenitasnya. Data yang diuji adalah skor postest kemampuan pemahaman dan kemampuan penalaran siswa di kedua kelompok.

\section{Hasil Penelitian}

\section{Kemampuan Pemahaman Matematika}

Hasil analisis data terhadap skor tes kemampuan pemahaman matematika siswa diperoleh skor terendah $\left(\bar{x}_{\min }\right)$, skor tertinggi $\left(\bar{x}_{\max }\right)$ skor rata-rata $\left(x_{\text {rerata }}\right)$ dan deviasi standar (s) untuk kelompok eksperimen dan kelompok kontrol seperti tampak pada Tabel1 berikut ini.

Dari table berikut tampak bahwa skor rata-rata tes kemampuan pemahaman matematis pada kelompok eksperimen adalah 77,70 (s=8,77) lebih tinggi dari skor rata-rata tes kemampuan pemahaman di kelompok kontrol yaitu 70,20 (s = 12,16). 
Tabel 1. Skor Tes Pemahaman

Matematika

\begin{tabular}{|c|c|c|c|c|c|}
\hline $\begin{array}{c}\text { Kelom } \\
\text { pok }\end{array}$ & $\begin{array}{c}\text { SM } \\
\text { I }\end{array}$ & $\left(\bar{x}_{\text {min }}\right)$ & $\left(\bar{x}_{\max }\right.$ & ( $x_{\text {rerata }}$ & $(s)$ \\
\hline $\begin{array}{l}\text { Eksper } \\
\text { imen }\end{array}$ & 100 & 60 & 95 & 77,7 & 8,77 \\
\hline $\begin{array}{l}\text { Kontro } \\
1\end{array}$ & 100 & 50 & 90 & 70,2 & 12,16 \\
\hline
\end{tabular}

Berdasarkan kriteria ketuntasan belajar bahwa banyaknya siswa kelas kontrol yang tuntas belajar hanya 19 orang dari 35 siswa atau 54,3\%, sedangkan banyaknya siswa yang tuntas untuk kelas eksperimen adalah 29 orang dari 35 siswa atau 82,3 \%. Dengan demikian, secara klasikal siswa kelompok kontrol belum memenuhi kriteria ketuntasan, sedangkan siswa kelompok eksperimen telah memenuhi kriteria ketuntasan yaitu $80 \%$ siswa memiliki skor > 65. Kesimpulan diperoleh bahwa persentase ketuntasan siswa kelompok eksperimen lebih besar dari ketuntasan siswa di kelas kontrol dengan selisih sebesar $28 \%$. Hal ini menunjukkan kemampuan pemahaman matematika siswa terhadap materi fungsi kuadrat kelas eksperimen lebih tinggi dari kemampuan pemahaman siswa di kelas kontrol.

\section{Kemampuan Penalaran}

Hasil analisis data terhadap skor tes kemampuan penalaran matematika siswa dalam bentuk soal uraian, diperoleh skor terendah $\left(\bar{x}_{\text {min }}\right)$, skor tertinggi $\left(\bar{x}_{\text {max }}\right)$, skor rata-rata ( $\left.x_{\text {rerata }}\right)$ dan deviasi standar $(s)$ untuk kelompok eksperimen dan kelompok kontrol seperti tampak pada Tabel berikut ini.
Tabel 2. Skor Tes Penalaran Matematika Siswa

\begin{tabular}{|c|c|c|c|c|c|}
\hline $\begin{array}{c}\text { Kelom } \\
\text { pok }\end{array}$ & $\begin{array}{c}\text { S } \\
\mathbf{M I}\end{array}$ & $\left(\bar{x}_{\min }\right)$ & $\left(\bar{x}_{\max }\right)$ & ( $x_{\text {rerat }}$ & $(s)$ \\
\hline $\begin{array}{l}\text { Eksper } \\
\text { imen }\end{array}$ & $\begin{array}{c}10 \\
0\end{array}$ & 60 & 95 & 78,9 & 9,07 \\
\hline $\begin{array}{l}\text { Kontro } \\
1\end{array}$ & $\begin{array}{c}10 \\
0\end{array}$ & 50 & 90 & 70,1 & $\begin{array}{c}11,9 \\
7\end{array}$ \\
\hline
\end{tabular}

Tabel di atas menunjukkan bahwa skor rata-rata tes penalaran matematis pada kelompok eksperimen adalah 78,90 ( $\mathrm{s}=$ 9,07) dan kelompok kontrol diperoleh skor rata-rata $70,1(\mathrm{~s}=$. Berdasarkan kriteria ketuntasan belajar bahwa banyaknya siswa kelas kontrol yang tuntas belajar hanya 21 orang dari 35 siswa atau $60 \%$. sedangkan banyaknya siswa yang tuntas untuk kelas eksperimen adalah 29 orang dari 35 siswa atau 82,3\%. Dengan demikian, secara klasikal siswa kelompok kontrol belum memenuhi kriteria ketuntasan, sedangkan siswa kelompok eksperimen telah memenuhi kriteria ketuntasan yaitu $80 \%$ siswa memiliki skor $>$ 65. Persentase ketuntasan siswa kelompok eksperimen lebih besar dari ketuntasan siswa di kelas kontrol dengan selisih sebesar 22,3\%. Hal ini menunjukkan kemampuan penalaran matematika siswa terhadap materi fungsi kuadrat kelas eksperimen lebih tinggi dari kemampuan penalaran siswa kelas kontrol.

\section{Aktivitas Pembelajaran Kelas Eksperimen}

Berdasarkan hasil analisis data tentang aktivitas pembelajaran di kelas eksperimen dan kelompok kontrol, siswa belajar secara aktif terhadap pembelajaran yang diterimanya. Namun, jika dilihat 
persentase keaktifan siswa maka siswa di kelompok eksperimen yang menggunakan software Autograph lebih aktif selama pembelajaran. Terlebih lagi jika membandingkan keaktifan siswa ketika berdiskusi, mengerjakan kuis, menggunakan media pembelajaran, dan saat membuat kesimpulan. Pada kegiatan tersebut siswa di kelompok eksperimen jauh lebih aktif dari siswa di kelompok kontrol.

Perbedaan di atas dikarenakan langkah-langkah pembelajaran dengan pendekatan penemuan terbimbing dengan software AUTOGRAPH mengharuskan siswa untuk aktif mencari, menyusun sendiri pengetahuannya. Disini terlihat jelas bahwa peran software AUTOGRAPH sangat membantu siswa membentuk pemahaman dan penalaran matematika dengan cara mengeksplorasi lebih banyak.

Dari perbandingan di atas dapat disimpulkan bahwa pendekatan penemuan terbimbing denga software AUTOGRAPH dapat membuat siswa lebih aktif selama pembelajaran dibandingkan tanpa software AUTOGRAPH. Dengan penemuan terbimbing siswa lebih aktif melakukan investigasi, bereksplorasi dan mengkonstruksi pengetahuannya dan dengan bantuan Autograph sebagai media siswa terbantu selama proses penemuan-nya. Sedangkan siswa yang belajar tanpa Autograph cenderung enggan untuk mengerjakan latihan lebih banyak.

\section{Sikap Siswa Terhadap Pembelajaran Matematika}

Hasil analisis data tentang sikap siswa terhadap pembelajaran matematika di kelas eksperimen menunjukkan sikap yang lebih baik. Secara keseluruhan sikap siswa terhadap pelajaran matematika menunjukkan sikap yang positif. Hasil analisis sikap siswa menunjukkan rata-rata sikap siswa lebih besar daripada skor netral yaitu 3,00.

\section{Kesimpulan}

Berdasarkan hasil temuan, beberapa simpulan tentang pemahaman dan penalaran matematika siswa. Pertama, siswa yang memperoleh pembelajaran dengan pendekatan penemuan terbimbing berbantuan Software Autograph mempunyai pemahaman dan penalaran matematika secara signifikan lebih baik jika dibandingkan dengan siswa yang memperoleh pembelajaran dengan penemuan terbimbing tanpa Autograph. Kedua, aktivitas belajar siswa yang memperoleh pendekatan penemuan terbimbing berbantuan Software Autograph lebih tinggi dari siswa yang memperoleh pendekatan penemuan terbimbing tanpa Autograph. Menurut kriteria ketuntasan minimal klasikal, siswa yang memperoleh pendekatan penemuan terbimbing berbantuan Software Autograph telah mencapai ketuntasan minimal, sedangkan siswa yan belajar dengan pendekatan penemuan terbimbing tanpa Autograph juga telah mencapai ketuntasan minimal tetapi persentasi kentuntasan siswa yang menggunakan Autograph lebih tinggi dari persentase sisa yang belajar tanpa Autograph. 


\section{Saran}

Berdasarkan simpulan di atas maka dalam pembelajaran matematika: (1) sebaiknya guru dan siswa menerapkan pendekatan penemuan terbimbing pada materi yang sesuai sebagai salah satu alternatif pendekatan pembelajaran dan menggunakan media belajar seperti software Autograph agar dapat lebih meningkatkan keaktifan dan keterlibatan siswa dalam belajar dan dapat meningkatkan pemahaman dan penalarannya; (2) sebaiknya guru dan siswa menerapkan pendekatan penemuan terbimbing pada materi yang sesuai sebagai salah satu alternatif pendekatan pembelajaran dan menggunakan media belajar seperti software Autograph karena dapat lebih meningkatkan ketuntasan belajar dan aktivitas belajar siswa dibandingkan siswa yang belajar tanpa software AUTOGRAPH.

\section{Pustaka}

Anggriamurti, Ranty Aditya. 2009. Pembelajaran Transformasi Geometri dengan Pendekatan Konstruktivis untuk Meningkatkan Penalaran Logis Siswa Kelas XII SMA BPI 2 Bandung (Online) (Http://www.terc.edu/indek/php/ht $\mathrm{ml}$ ), diakses tanggal 1 Oktober 2009)

Arikunto, S. 1997. Prosedur Penelitian suatu Pendekatan Praktek. Jakarta: Rineka Cipta.

Arikunto, S. 2003. Dasar - dasar Evaluasi Pendidikan, Edisi Revisi, Cetakan Keempat, Bumi Aksara, Jakarta.
Arsyad, Azhar. 2005. Media Pembelajaran. Jakarta: Raja Grafindo Persada.

Butler, Douglas. 2007. Autograph, www.Autograph-math.com

Clement, DH. \& Battista, M.T. 2001. Constructivist Learning and Teaching

(Online)(Http://www.terc.edu/inves tigation/relevant/html/construtivistl earning html, diakses tanggal 14 Agustus 2008)

Dahar, Ratna Willis. 1996. Teori-teori Belajar. Jakarta: Departemen Pendidikan dan Kebudayaan, Direktorat Jenderal Pendidikan Tinggi, Proyek Pengembangan Lembaga Pendidikan dan Tenaga Kependidikan.

Depdikbud. 1996. Kamus Besar Bahasa Indonesia, Balai Pustaka, Jakarta.

Depdiknas. 2006. Standar Kompetensi Lulusan untuk Satuan Pendidikan Dasar dan Menengah. Jakarta: Direktorat Jenderal Pendidikan Dasar dan Menengah.

Driver, R dan Leach, J. 1993. A Constructivist view of Learning: Children's Conception and Nature of Science. What Research Says to The Science Teacher. 7, 103-112. Washington: National Science Teacher Association.

Hasanah, A. 2004. Mengembangkan Kemampuan Pemahaman dan Penalaran Matematika Siswa Sekolah Menengah Pertama melalui Pembelajaran Berbasis Masalah yang Menekankan pada 
Representasi Matematik. Tesis tidak diterbitkan. Bandung: Program Pascasarjana UPI Bandung. .

Hierbet, James, Carpenter, Thomas, P. 1992. Learning and Teaching with Understanding. In Grows. Handbook of Research on Mathematics Teaching and Learning. 65-97. New York: Mac Millan.

Hudojo, H. 1998. Mengajar Belajar Matematika. Depdikbud

Jarnawi. 2003. Meningkatkan Kemampuan Penalaran Dan Pemahaman Matematika Siswa Sekolah Lanjutan Tingkat Pertama Melalui Pendekatan Pembelajaran OpenEnded, Studi Eksperimen Pada Siswa Sekolah Lanjutan Pertama Negeri Di Kota Bandung. Disertasi tidak diterbitkan. Bandung: Program Pascasarjana UPI Bandung.

Kuhlthau. Carol Collier. 2007. Guided Inquiry: Learning in The $21^{\text {st }}$ Century School. Westport, CT: Libraries Unlimited.

Kurnia, Asep. 2004. Meningkatkan hasil belajar matematika siswa SMU melalui pembelajaran berdasarkan masalah dengan metode penemuan : studi eksperimen pada SMUN 15 Bandung dan SMU Kartika Chandra III-2 Bandung. (online). (http://digilib.upi.edu/pasca/availab le/etd-1005106-143918/ diakses pada tanggal 23 Juni 2009)
Markaban. 2006. Model Pembelajaran Matematika dengan Pendekatan Penemuan Terbimbing. Modul Paket Pembinaan Penataran Guru: Tidak Diterbitkan.

Maryati, Yusi. 2007. Perbandingan Peningkatan Prestasi Belajar Matematika antara Siswa SMP yang Mendapat Pembelajaran Model Penemuan Terbimbing dan Model Treffinger (Penelitian Eksperimen Terhadap Siswa Kelas VIII SMP Negeri 29 Bandung). (Online).( http://digilib.upi.edu/pasca/availabl e/etd-0225108-114011/ diakses pada tanggal 23 Juni 2009)

Pannen, P. 2001. Konstruktivisme dalam Pembelajaran. Jakarta: PAU-PPAI, UT

Ruseffendi, E.T. 1994. Dasar-dasar Penelitian Pendidikan dan Bidang Non Eksakta Lainnya. Semarang: IKIP Semarang Press.

Ruseffendi, E.T. 1998. Pengantar kepada Membantu Guru Mengembangkan Kompetensinya dalam Pengajaran Matematika untuk Meningkatkan CBSA. Bandung: Tarsito.

Shadiq, Fajar. 2004. Penalaran, Pemecahan Masalah dan Komunikasi dalam Pembelajaran Matematika. Makalah yang disajikan dalam Diklat/Pengembangan Matematika SMP jenjang dasar, PPPG Matematika Yogyakarta, Yogyakarta, 10-23 Oktober 2004. 
Sudjana. 1996. Metoda Statistika. Bandung: Tarsito

Sulistianti, S. (2008). Pembelajaran Logika Matematika Dengan Pendekatan Kontekstual (Contextual Teaching and Learning) Dalam Upaya Meningkatkan Kemampuan Penalaran Logis. Skripsi. Jurusan Pendidikan FPMIPA UPI: Tidak Diterbitkan

Suriadi. 2006. Pembelajaran dengan pendekatan discovery yang menekankan aspek analogi untuk meningkatkan pemahaman matematik dan kemampuan berpikir kritis siswa SMA. Tesis tidak diterbitkan. Bandung: Program Pascasarjana UPI Bandung.

Sutrisno. 2005. Metodologi Research (Jilid - 3). Yogyakarta: ANDI Yogyakarta

Utari. 1999. Kemampuan pemahaman matematika sistem SMA dikaitkan dengan kemampuan penalaran logik siswa dan beberapa unsur proses belajar mengajar, studi deskriptif analitis terhadap siswa SMA Negeri dari tujuh Kota di Jawa Barat. Disertasi tidak diterbitkan. Bandung: Program Pascasarjana UPI Bandung.

Voigt, Jorg. 1996. Theories of Mathematical Learning. New Jersey: Lawrence Erlbaum Associates Publishers.

Wardhani, Inne. 2006. Efektivitas Penggunaan Komputer dalam Pembelajaran Matematika Interaktif Model Tutorial untuk Meningkatkan Kemampuan Berpikir Kritis dan Motivasi Belajar Matematik Siswa SMA (Suatu Penelitian terhadap Siswa Kelas XI SMA Negeri 1 Tarogong Kidul Garut pada Pokok Bahasan Peluang).

(Online). (http://digilib.upi.edu/pasca/availab le/etd-0225108-114011/ diakses pada tanggal 23 Juni 2009) 